\title{
Dietzia kunjamensis sp. nov., isolated from the Indian Himalayas
}

\author{
Correspondence \\ S. Mayilraj \\ mayil@imtech.res.in
}

\author{
S. Mayilraj, ${ }^{1}$ K. Suresh, ${ }^{1}$ R. M. Kroppenstedt ${ }^{2}$ and H. S. Saini ${ }^{3}$ \\ ${ }^{1}$ Microbial Type Culture Collection and Gene Bank (MTCC), Institute of Microbial Technology, \\ Sector 39-A, Chandigarh, 160 036, India \\ ${ }^{2} \mathrm{DSMZ}$ - Deutsche Sammlung von Mikroorganismen und Zellkulturen GmbH, Mascheroder \\ Weg 1B, 38124 Braunschweig, Germany \\ ${ }^{3}$ Department of Microbiology, Guru Nanak Dev University (GNDU), Amritsar, 143 005, India
}

The genus Dietzia was proposed to accommodate organisms previously classified as Rhodococcus maris (Rainey et al., 1995). Members of the genus Dietzia are distributed in a variety of habitats like marine, soil and hospital environments (Rainey et al., 1995; Colquhoun et al., 1998; Duckworth et al., 1998; Yassin et al., 2006). At the time of writing, the genus comprises four species, namely Dietzia maris (Rainey et al., 1995), Dietzia natronolimnaea (Duckworth et al., 1998), Dietzia psychralcaliphila (Yumoto et al., 2002) and Dietzia cinnamea (Yassin et al., 2006).

Strain K30-10 ${ }^{\mathrm{T}}$ was isolated from a soil sample collected from Kunjam Pass, a cold desert of the Indian Himalayas. After primary isolation on tryptic soya agar medium (TSA; HiMedia), the strain was maintained as glycerol stocks at $-70{ }^{\circ} \mathrm{C}$. The type strains D. maris MTCC $7011^{\mathrm{T}}$ (=DSM $\left.43672^{\mathrm{T}}\right)$, D. natronolimnaea MTCC $7014^{\mathrm{T}}\left(=\mathrm{DSM} 44860^{\mathrm{T}}\right)$, D. psychralcaliphila MTCC $7010^{\mathrm{T}}\left(=\mathrm{DSM} 44820^{\mathrm{T}}\right)$ and D. cinnamea MTCC $7506^{\mathrm{T}}\left(=\mathrm{DSM} 44904^{\mathrm{T}}\right)$ were obtained from the Microbial Type Culture Collection and Gene Bank (MTCC), Chandigarh, India.

Morphological properties, motility, Gram staining, acid-fast staining and endospore staining were studied according to standard protocols (Murray et al., 1994). Gram reaction was determined using the HiMedia Gram Staining kit according

The GenBank/EMBL/DDBJ accession number for the $16 \mathrm{~S}$ rRNA gene sequence of strain $\mathrm{K} 30-10^{\top}$ is AY972480. to the manufacturer's instructions. Physiological tests like growth at different temperatures, $\mathrm{pH}$ and $\mathrm{NaCl}$ concentrations (under neutral $\mathrm{pH}$ ) were examined by growing the strain on basal tryptic soy broth medium (TSB). Utilization of various substrates as sole carbon sources was tested using Biolog GP2 MicroPlates in accordance to the manufacturer's instructions, except that TSA was used instead of Biolog Universal Growth agar medium. The inoculated plates were incubated for $24 \mathrm{~h}$ and the results were read with a MicroPlate Reader using Microlog 4.2 software. Catalase and urea hydrolysis were determined as described by Cowan \& Steel (1965). Hydrolysis of casein, gelatin, Tween 80 and starch, and the oxidase reaction (using $N, N, N^{\prime}, N^{\prime}$ tetramethyl- $p$-phenylenediamine dihydrochloride) were determined as described by Smibert \& Krieg (1994). Nitrate reduction was determined as described by Lanyi (1987). Acid production from various sugars (at $0.5 \%$ ) was tested on minimal medium $\left(\mathrm{MgSO}_{4} .7 \mathrm{H}_{2} \mathrm{O}, 0.5 \mathrm{~g} ; \mathrm{NaCl}\right.$, $0.5 \mathrm{~g} ; \mathrm{FeSO}_{4} .7 \mathrm{H}_{2} \mathrm{O}, 0.01 \mathrm{~g} ; \mathrm{K}_{2} \mathrm{HPO}_{4}, 1.0 \mathrm{~g}$; yeast extract, $0.2 \mathrm{~g}$; distilled water, $1 \mathrm{l} ; 0 \cdot 2 \%$ solution bromocresol blue used as indicator). Cell-wall sugars and diagnostic amino acids were determined as described by Staneck \& Roberts (1974). Phospholipids and menaquinones were extracted and analysed as described by Minnikin et al. (1984). The presence of mycolic acids was demonstrated by TLC (Minnikin \& Goodfellow, 1976) and the mycolic acid pattern was determined according to Klatte et al. (1994). The glycolic acid content of the bacterial cell wall was determined as described by Uchida \& Aida (1984). For cellular fatty acid analysis, all strains were grown on TSA at $30^{\circ} \mathrm{C}$ for 
Table 1. Phenotypic properties, mycolic acid chain length and $\mathrm{G}+\mathrm{C}$ content of $\mathrm{K} 30-10^{\top}$ and type strains of Dietzia species

Strains: 1, strain K30-10 ${ }^{\mathrm{T}}$; 2, D. psychralcaliphila MTCC $7010^{\mathrm{T}}$; 3, D. maris MTCC $7011^{\mathrm{T}}$; 4, D. natronolimnaea MTCC $7014^{\mathrm{T}}$; 5, D. cinnamea MTCC $7506^{\mathrm{T}}$. All data are from the present study. All were negative for: endospore production; $\mathrm{H}_{2} \mathrm{~S}$ production; indole; methyl red and Voges-Proskauer tests; hydrolysis of casein, DNA and starch; growth at $\mathrm{pH} 5$; acid production from glucose, lactose, rhamnose and mannose; and utilization of $\alpha$ - and $\beta$-cyclodextrin, glycogen, inulin, mannan, $N$-acetyl-D-glucosamine, $N$-acetyl- $\beta$-D-mannosamine, amygdalin, D-arabitol, arbutin, D-cellobiose, D-galactose, D-galacturonic acid, D-gluconic acid, myo-inositol, $\alpha$-D-lactose, lactulose, maltose, D-mannitol, D-melezitose, D-melibiose, methyl $\alpha$-D-galactoside, methyl $\beta$-D-galactoside, methyl-D-glucose, methyl $\beta$-D-glucoside, methyl $\alpha$-Dmannoside, D-raffinose, L-rhamnose, salicin, sedoheptulosan, D-sorbitol, stachyose, sucrose, xylitol, $\alpha$-hydroxybutyric acid, $p$-hydroxyphenylacetic acid, $\alpha$-ketoglutaric acid, lactamide, D-lactic acid methyl ester, L-lactic acid, D- and L-malic acid, succinamic acid, $\mathrm{N}$-acetyl-L-glutamic acid, L-alaninamide, D- and L-alanine, L-alanyl glycine, glycyl L-glutamic acid, L-pyroglutamic acid, putrescine, 2,3-butanediol, adenosine, 2'-deoxyadenosine, inosine, uridine, AMP, TMP, UMP, citrate and DL- $\alpha$-glycerol phosphate.

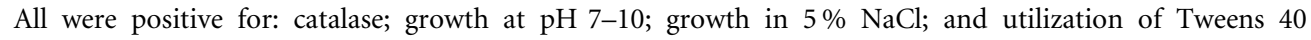
and 80 , D-fructose, $\alpha$-D-glucose, D-mannose, palatinose, D-psicose, D-ribose, D-trehalose, acetic acid, $\beta$-hydroxybutyric acid, $\alpha$-ketovaleric acid, propionic acid and pyruvic acid as carbon sources. + , Positive; -, negative; $\mathrm{W}$, weakly positive; ND, not determined.

\begin{tabular}{|c|c|c|c|c|c|}
\hline Characteristic & 1 & 2 & 3 & 4 & 5 \\
\hline Colony colour* & $\mathrm{CR}$ & $\mathrm{CR}$ & $\mathrm{O}$ & CR & $\mathrm{O}$ \\
\hline Oxidase reaction & + & + & - & - & $\mathrm{W}$ \\
\hline Nitrate reduction & + & - & + & - & + \\
\hline Gelatin hydrolysis & - & $\mathrm{W}$ & $\mathrm{W}$ & - & + \\
\hline Urea hydrolysis & - & - & - & - & + \\
\hline \multicolumn{6}{|c|}{ Growth in $\mathrm{NaCl}$ at neutral $\mathrm{pH}$ : } \\
\hline $7 \%$ & $\mathrm{~W}$ & + & + & + & + \\
\hline 8 and $10 \%$ & - & + & - & + & + \\
\hline $12 \%$ & - & - & - & - & $\mathrm{W}$ \\
\hline Growth at $5^{\circ} \mathrm{C}$ & - & + & - & - & - \\
\hline Growth at $42^{\circ} \mathrm{C}$ & - & - & + & + & + \\
\hline \multicolumn{6}{|c|}{ Acid production (aerobically): } \\
\hline Arabinose & - & + & + & - & - \\
\hline Cellobiose & - & + & - & - & + \\
\hline Fructose & - & - & - & - & + \\
\hline Galactose & - & - & - & - & + \\
\hline Maltose & - & + & + & + & + \\
\hline Mannitol & + & - & - & - & + \\
\hline Raffinose & - & + & + & - & - \\
\hline Salicin & - & - & - & - & + \\
\hline Sorbitol & - & - & - & - & + \\
\hline Sucrose & + & + & - & + & - \\
\hline Xylose & - & + & - & - & + \\
\hline \multicolumn{6}{|c|}{ Utilization as sole carbon source: } \\
\hline Dextrin & + & + & - & + & - \\
\hline L-Arabinose & + & + & + & - & + \\
\hline L-Fucose & + & - & - & - & + \\
\hline Gentiobiose & + & - & - & + & - \\
\hline Maltotriose & + & - & - & - & + \\
\hline Methyl $\alpha$-D-glucoside & - & - & - & + & + \\
\hline Sucrose & - & + & + & + & - \\
\hline Succinic acid & - & - & - & - & + \\
\hline D-Tagatose & - & - & - & + & + \\
\hline Turanose & + & + & - & + & + \\
\hline D-Trehalose & + & + & + & + & - \\
\hline D-Xylose & + & - & + & - & + \\
\hline
\end{tabular}


Table 1. cont.

\begin{tabular}{|lccccc|}
\hline Characteristic & $\mathbf{1}$ & $\mathbf{2}$ & $\mathbf{3}$ & $\mathbf{4}$ & $\mathbf{5}$ \\
\hline$\gamma$-Hydroxybutyric acid & + & - & + & - & - \\
Pyruvic acid methyl ester & - & + & - & - & - \\
Succinic acid monomethyl ester & + & - & + & + & + \\
L-Asparagine & + & - & - & - & + \\
L-Glutamic acid & + & - & - & - & + \\
L-Serine & - & - & + & - & - \\
Glycerol & + & - & + & - & - \\
Thymidine & + & - & - & - & - \\
D-Fructose 6-phosphate & + & - & + & + & + \\
$\alpha$-D-Glucose 1-phosphate & - & - & - & - & + \\
D-Glucose 6-phosphate & - & - & - & $34-38$ & ND \\
Mycolic acid chain length & $33-40$ & $34-39$ & $33-38$ & $34 \cdot 1$ & ND \\
DNA G+C content (mol\%) & $67 \cdot 2$ & $69 \cdot 6$ & $70 \cdot 4$ & $66 \cdot 1$ & \\
\end{tabular}

${ }^{*} \mathrm{CR}$, Coral-red; O, orange.

$36 \mathrm{~h}$ and fatty acid methyl ester analysis was performed with the Sherlock Microbial Identification System (MIDI) as described previously (Pandey et al., 2002).

Genomic DNA extraction, amplification and 16S rRNA gene sequencing were performed as described previously (Mayilraj et al., 2005). DNA-DNA hybridization was performed each time with freshly isolated genomic DNA and was repeated three times by the membrane filter method (Tourova \& Antonov, 1987). The genomic DNA G +C content was determined spectrophotometrically (Lambda

Table 2. Fatty acid compositions of strain $\mathrm{K} 30-10^{\top}$ and type strains of Dietzia species

Strains: 1, strain $\mathrm{K} 30-10^{\mathrm{T}}$; 2, D. psychralcaliphila MTCC $7010^{\mathrm{T}}$; 3, D. maris MTCC $7011^{\mathrm{T}}$; 4, D. natronolimnaea MTCC $7014^{\mathrm{T}}$; 5 , D. cinnamea MTCC $7506^{\mathrm{T}}$. Values are percentages of total fatty acids; all data are from the present study.

\begin{tabular}{|lccccc|}
\hline Fatty acid & $\mathbf{1}$ & $\mathbf{2}$ & $\mathbf{3}$ & $\mathbf{4}$ & $\mathbf{5}$ \\
\hline $14: 0$ & $0 \cdot 36$ & $0 \cdot 44$ & $0 \cdot 81$ & $0 \cdot 66$ & $0 \cdot 65$ \\
$15: 1$ cis-10 & - & - & $0 \cdot 24$ & - & $0 \cdot 46$ \\
$15: 0$ & $2 \cdot 88$ & $1 \cdot 63$ & $14 \cdot 53$ & $0 \cdot 79$ & $4 \cdot 66$ \\
$16: 1$ cis-9 & $1 \cdot 50$ & $5 \cdot 38$ & $1 \cdot 92$ & $5 \cdot 37$ & $2 \cdot 35$ \\
$16: 1$ cis-10 & $6 \cdot 00$ & $3 \cdot 78$ & $5 \cdot 53$ & $8 \cdot 29$ & $12 \cdot 17$ \\
$16: 0$ & $14 \cdot 43$ & $25 \cdot 65$ & $17 \cdot 04$ & $28 \cdot 50$ & $22 \cdot 97$ \\
$10-$ Methyl $16: 0$ & - & - & - & - & $0 \cdot 56$ \\
$17: 1$ cis-9 & $8 \cdot 85$ & $9 \cdot 26$ & $25 \cdot 46$ & $3 \cdot 49$ & $11 \cdot 43$ \\
$17: 1$ cis-10 & $7 \cdot 41$ & - & - & - & - \\
$17: 0$ & $12 \cdot 95$ & $4 \cdot 78$ & $8 \cdot 09$ & $2 \cdot 10$ & $3 \cdot 96$ \\
$10-$ Methyl $17: 0$ & $0 \cdot 99$ & - & $4 \cdot 23$ & - & $5 \cdot 23$ \\
$18: 1$ cis-9 & $30 \cdot 39$ & $35 \cdot 55$ & $15 \cdot 95$ & $31 \cdot 06$ & $13 \cdot 49$ \\
$18: 0$ & $0 \cdot 84$ & - & $0 \cdot 52$ & $0 \cdot 75$ & $0 \cdot 32$ \\
$10-$ Methyl $18: 0$ & $10 \cdot 51$ & $13 \cdot 52$ & $4 \cdot 63$ & $18 \cdot 26$ & $20 \cdot 65$ \\
$19: 1$ cis-9 & $2 \cdot 59$ & - & $0 \cdot 87$ & $0 \cdot 73$ & $1 \cdot 10$ \\
\hline
\end{tabular}

35; Perkin Elmer) using the thermal denaturation method (Mandel \& Marmur, 1968). Phylogenetic analysis was carried out as described previously (Mayilraj et al., 2005).

Chemical and phenotypic properties of strain $\mathrm{K} 30-10^{\mathrm{T}}$ were consistent with its classification in the genus Dietzia. Detailed characteristics are given in Table 1 and the species description. The fatty acid compositions of strain $\mathrm{K} 30-10^{\mathrm{T}}$ and the type strains of the four species of the genus Dietzia are shown in Table 2 . The fatty acid methyl ester profile matches qualitatively with that of other species of the genus Dietzia. However, strain K30-10 ${ }^{\mathrm{T}}$ contained a significant amount of $17: 1$ cis-10 (cis-10-heptadecenoic acid, 7·41\%), which was absent from the other species. The 16S rRNA gene sequence of strain $\mathrm{K} 30-10^{\mathrm{T}}$ generated in this work (1455 bases) was aligned with sequences of other species of the genus Dietzia retrieved from GenBank. Phylogenetic

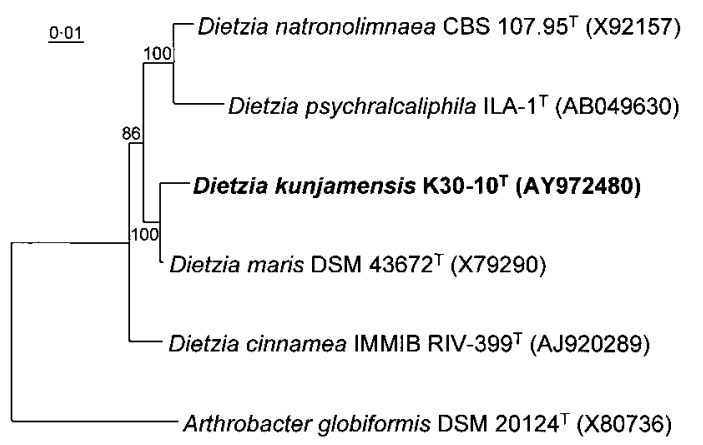

Fig. 1. Neighbour-joining tree based on 16S rRNA gene sequences (1455 bases) showing the phylogenetic relationship between strain Dietzia kunjamensis sp. nov. $\mathrm{K} 30-10^{\top}$ and other species of the genus Dietzia. Arthrobacter globiformis DSM $20124^{\top}$ was used as an outgroup. Bootstrap values (expressed as percentages of 1000 replications) greater than $50 \%$ are given at the nodes. Bar, $1 \%$ sequence variation. 
analysis based on $16 \mathrm{~S}$ rRNA gene sequences revealed that strain $\mathrm{K} 30-10^{\mathrm{T}}$ formed a separate branch within the lineage including D. maris (Fig. 1). Highest sequence similarity $(97.9 \%)$ was found with $D$. maris DSM $43672^{\mathrm{T}}$, whereas sequences from other species of the genus Dietzia were $94 \cdot 4-96 \cdot 0 \%$ similar. DNA-DNA hybridization was performed in triplicate under optimal conditions to determine the genetic relatedness between $\mathrm{K} 30-10^{\mathrm{T}}$ and $D$. maris MTCC $7011^{\mathrm{T}}$. The DNA-DNA relatedness value between these two strains was $59 \cdot 2 \%$ (mean of $62 \cdot 4,56 \cdot 7$ and $58.6 \%$ ), which is well below the $70 \%$ cut-off value recommended for the delineation of bacterial species (Wayne et al., 1987). The DNA-DNA relatedness between strain $\mathrm{K} 30-10^{\mathrm{T}}$ and strains of other Dietzia species was not determined, since it has been shown that organisms with more than $3 \% 16 \mathrm{~S}$ rRNA gene sequence dissimilarity belong to different genomic species (Stackebrandt \& Goebel, 1994). On the basis of genotypic and phenotypic data, strain K30$10^{\mathrm{T}}$ is very clearly distinguishable from species most closely related to it. Therefore, strain $\mathrm{K} 30-10^{\mathrm{T}}$ represents a novel species of the genus Dietzia, for which the name Dietzia kunjamensis sp. nov. is proposed.

\section{Description of Dietzia kunjamensis sp. nov.}

Dietzia kunjamensis (kun.ja.men'sis. N.L. fem. adj. kunjamensis pertaining to Kunjam Pass of the cold desert of the Indian Himalayas).

Cells are aerobic, Gram-positive, acid-fast, non-motile and non-endospore-forming. They are rod- and coccoid-like $(1 \cdot 0-1 \cdot 2 \times 1 \cdot 1-2 \cdot 0 \mu \mathrm{m})$ and occur in groups. Colonies on TSA are coral-red-pigmented, small, smooth, glistening and convex. Catalase is produced. Negative for $\mathrm{H}_{2} \mathrm{~S}$ production, indole, methyl red and Voges-Proskauer tests and hydrolysis of casein, DNA and starch. Tolerates up to $5 \% \mathrm{NaCl}$ and grows at temperatures between 20 and $37^{\circ} \mathrm{C}$, with an optimum growth temperature of $25^{\circ} \mathrm{C}$. Grows at $\mathrm{pH} 7-10$; optimum growth at $\mathrm{pH} 8 \cdot 0$. Other phenotypic characteristics and utilization of compounds as sole carbon sources are given in Table 1. The cell-wall amino acid is mesodiaminopimelic acid and the major cell-wall sugars are arabinose and galactose. The acyl type of the glycan chain of peptidoglycan is acetyl. Whole-cell fatty acids consist of predominantly straight-chain saturated and unsaturated fatty acids, $\mathrm{C}_{16: 0}(14 \cdot 43 \%), \mathrm{C}_{16: 1} 10 c(6 \cdot 00 \%), \mathrm{C}_{17: 0}$ $(12 \cdot 95 \%), \mathrm{C}_{17: 1} 10 c(7 \cdot 41 \%), \mathrm{C}_{18: 1} 9 c(30 \cdot 39 \%)$ and 10 methyl $\mathrm{C}_{18: 0}$ (tuberculostearic acid, $10 \cdot 51 \%$ ). Short-chain mycolic acids are present (33-40 carbon atoms). The polar lipids present are phosphatidylinositol, phosphatidylglycerol and diphosphatidylglycerol. Major menaquinone is MK- $8\left(\mathrm{H}_{2}\right)$. The DNA G $+\mathrm{C}$ content of the type strain is $67 \cdot 0 \mathrm{~mol} \%$.

The type strain is $\mathrm{K} 30-10^{\mathrm{T}} \quad\left(=\right.$ MTCC $7007^{\mathrm{T}}=\mathrm{DSM}$ $44907^{\mathrm{T}}=\mathrm{JCM} 13325^{\mathrm{T}}$ ), isolated from soil, $45 \mathrm{~cm}$ below an ice glacier, at $4200 \mathrm{~m}$ above sea level, Kunjam Pass, Himachal Pradesh, India.

\section{Acknowledgements}

We thank Professor Dr Hans G. Trüper, Institute for Microbiology and Biotechnology, Rheinische Friedrich-Wilhelm-University, Bonn, Germany, for his suggestion on Latin nomenclature for the novel species. We would like to thank Ms Gabi Poetter and Ms Marlen Jando, DSMZ, Germany, and Mr Malkit Singh, MTCC, for their excellent technical assistance. Financial assistance from DBT and CSIR, Government of India is duly acknowledged. This is IMTECH communication number 59/2005.

\section{References}

Colquhoun, J. A., Heald, S. C., Li, L., Tamaoka, J., Kato, C., Horikoshi, K. \& Bull, A. T. (1998). Taxonomy and biotransformation activities of some deep-sea actinomycetes. Extremophiles 2, 269-277.

Cowan, S. T. \& Steel, K. J. (1965). Manual for the Identification of Medical Bacteria. London: Cambridge University Press.

Duckworth, A. W., Grant, S., Grant, W. D., Jones, B. E. \& Meijer, D. (1998). Dietzia natronolimnaios sp. nov., a new member of the genus Dietzia isolated from an East African soda lake. Extremophiles 2, 359-366.

Klatte, S., Rainey, F. A. \& Kroppenstedt, R. M. (1994). Transfer of Rhodococcus aichiensis Tsukamura 1982 and Nocardia amarae Lechevalier and Lechevalier 1974 to the genus Gordona as Gordona aichiensis comb. nov. and Gordona amarae comb. nov. Int J Syst Bacteriol 44, 769-773.

Lanyi, B. (1987). Classical and rapid identification methods for medically important bacteria. Methods Microbiol 19, 1-67.

Mandel, M. \& Marmur, J. (1968). Use of ultraviolet absorbancetemperature profile for determining the guanine plus cytosine content of DNA. Methods Enzymol 12B, 195-206.

Mayilraj, S., Prasad, G. S., Suresh, K., Saini, H. S., Shivaji, S. \& Chakrabarti, T. (2005). Planococcus stackebrandtii sp. nov., isolated from a cold desert of the Himalayas, India. Int J Syst Evol Microbiol 55, 91-94.

Minnikin, D. E. \& Goodfellow, M. (1976). Lipid composition in the classification and identification of Nocardia and related taxa. In The Biology of the Nocardiaceae, pp. 160-219. Edited by M. Goodfellow, G. H. Brownell \& J. A. Serrano. London: Academic Press.

Minnikin, D. E., O’Donnell, A. G., Goodfellow, M., Alderson, G., Athalye, M., Schaal, K. \& Parlett, J. H. (1984). An integrated procedure for the extraction of bacterial isoprenoid quinones and polar lipids. J Microbiol Methods 2, 233-241.

Murray, R. G. E., Raymond, N., Doetsch, R. N. \& Robinow, C. F. (1994). Determinative and cytological light microscopy. In Methods for General and Molecular Bacteriology, pp. 21-41. Edited by P. Gerhardt, R. G. E. Murray, W. A. Wood \& N. R. Krieg. Washington, DC: American Society for Microbiology.

Pandey, K. K., Mayilraj, S. \& Chakrabarti, T. (2002). Pseudomonas indica sp. nov., a novel butane-utilizing species. Int $J$ Syst Evol Microbiol 52, 1559-1567.

Rainey, F. A., Klatte, S., Kroppenstedt, R. M. \& Stackebrandt, E. (1995). Dietzia, a new genus including Dietzia maris comb. nov., formerly Rhodococcus maris. Int J Syst Bacteriol 45, 32-36.

Smibert, R. M. \& Krieg, N. R. (1994). Phenotypic characterization. In Methods for General and Molecular Bacteriology, pp. 607-654. Edited by P. Gerhardt, R. G. E. Murray, W. A. Wood \& N. R. Krieg. Washington, DC: American Society for Microbiology.

Stackebrandt, E. \& Goebel, B. M. (1994). Taxonomic note: a place for DNA-DNA reassociation and 16S rRNA sequence analysis in the 
present species definition in bacteriology. Int J Syst Bacteriol 44, 846-849.

Staneck, J. L. \& Roberts, G. D. (1974). Simplified approach to identification of aerobic actinomycetes by thin-layer chromatography. Appl Microbiol 28, 226-231.

Tourova, T. P. \& Antonov, A. S. (1987). Identification of microorganisms by rapid DNA-DNA hybridization. Methods Microbiol 19, 333-355.

Uchida, K. \& Aida, K. (1984). An improved method for the glycolate test for simple identification of the acyl type of bacterial cell walls. J Gen Appl Microbiol 30, 131-134.
Wayne, L. G., Brenner, D. J., Colwell, R. R. \& 9 other authors (1987). International Committee on Systematic Bacteriology. Report of the ad hoc committee on reconciliation of approaches to bacterial systematics. Int J Syst Bacteriol 37, 463-464.

Yassin, A. F., Hupfer, H. \& Schaal, K. P. (2006). Dietzia cinnamea sp. nov., a novel species isolated from a perianal swab of a patient with a bone marrow transplant. Int J Syst Evol Microbiol 56, 641-645.

Yumoto, I., Nakamura, A., Iwata, H., Kojima, K., Kusumoto, K., Nodasaka, Y. \& Matsuyama, H. (2002). Dietzia psychralcaliphila sp. nov., a novel, facultatively psychrophilic alkaliphile that grows on hydrocarbons. Int J Syst Evol Microbiol 52, 85-90. 